\title{
Hubungan Tingkat Pengetahuan dan Sikap Dengan Perilaku Merokok Pada Pengunjung di Lantai Dua Coffe Banjarmasin
}

\author{
Relationship Between Knowledge Level and Attitude With Smoking Behavior in Visitors on \\ Banjarmasin Coffe Second Floor
}

\author{
Nurul Indah Qariati * ${ }^{1}$, Fahrurazi ${ }^{2}$, Rezky Dini Lasari ${ }^{3}$ \\ ${ }_{1,2,3}$ Fakultas Kesehatan Masyarakat Universitas Islam Kalimantan MAB Banjarmasin \\ *Email Korespondensi : qoiefkm@gmail.com
}

\begin{abstract}
Abstrak
Perilaku merokok merupakan masalah kesehatan masyarakat yang serius di dunia. Perilaku merokok dilihat dari sudut pandang mana saja sangat merugikan, baik untuk diri sendiri maupun orang disekitar. Tujuan dari penelitian ini adalah untuk mengetahui tingkat hubungan dan sikap dengan perilaku merokok pada pengunjung cafe lantai dua coffe Banjarmasin tahun 2018. Penelitian ini bersifat survei analitik dengan pendekatan Cross Sectional. Populasi dan sampel dalam peneitian ini sebanyak 150 responden dengan teknik pengambilan sebanyak $50 \%$ dari populasi yaitu didapat 75 responden. Instrumen penelitian yang digunakan adalah kuesioner, data dianalisis menggunakan uji statistik Chi Square yang diolah menggunakan program komputer dengan $\alpha=$ 0,05 . Hasil penelitian menunjukkan bahwa sebanyak 33 responden $(44,0 \%)$ tidak merokok, pengetahuan responden termasuk dalam kategori baik yaitu sebanyak 32 responden (42,7 \%). Sikap responden sebagian berada dalam kategori positif sebanyak 59 responden $(78,7 \%)$. Berdasarkan hasil uji statistik dengan menggunakan uji Chi Square menunjukkan ada hubungan antara tingkat pengetahuan dan sikap dengan perilaku merokok $(\mathrm{p}=0,015)$. Ada hubungan antara sikap dengan perilaku merokok $(\mathrm{p}=0,000)$. Saran agar lebih memperdulikan kesehatan, menumbuhkan kemauan yang tinggi untuk berhenti merokok, serta melakukan kegiatan yang lebih bermanfaat bagi diri maupun orang lain.
\end{abstract}

Kata Kunci : Tingkat pengetahuan, sikap, merokok

\begin{abstract}
Smoking is a serious public health problem in the world. Smoking behavior seen from any point of view is very detrimental, both for yourself and those around. The purpose of this study was to determine the level of relations and attitudes to smoking behavior in visitors to the cafe in the second floor of Banjarmasin coffee shop in 2018. This study was an analytical survey with a Cross Sectional approach. Population and sample in this study were 150 respondents with taking techniques as much as 50\% of the population that is obtained 75 respondents. The research instrument used was a questionnaire, the data were analyzed using Chi Square statistical test which was processed using a computer program with $\alpha=0.05$. The results showed that as many as 33 respondents (44.0\%) did not smoke, respondents' knowledge was included in the good category as many as 32 respondents (42.7\%). The attitude of the respondents was partly in the positive category as many as 59 respondents (78.7\%). Based on the results of statistical tests using the Chi Square test showed there was a relationship between the level of knowledge and attitudes with smoking behavior $(p=0.015)$. There is a relationship between attitude and smoking behavior $(p=0,000)$. Suggestions to be more concerned about health, foster a high willingness to stop smoking, and carry out activities that are more beneficial for themselves and others.
\end{abstract}

Keywords: Level of knowledge, attitude, smoking 


\section{PENDAHULUAN}

Perilaku merokok merupakan masalah kesehatan masyarakat yang serius di dunia. Badan Kesehatan Dunia (WHO), merilis bahwa dampak buruk yang diakibatkan oleh perilaku ini membunuh sekitar 6 juta orang per tahun, dimana lebih dari 5 juta dari korban tersebut adalah perokok aktif, mantan perokok dan pengguna "smokeless tobacco"(jenis tembakau hisap tanpa proses pembakaran). Ironisnya, lebih dari 600 ribu korban merupakan perokok pasif atau orang yang berada di sekitar perokok dan turut menghirup asap/uap rokok secara tidak langsung [1].

Perilaku merokok merupakan fungsi dari lingkungan dan individu. Artinya, perilaku merokok selain disebabkan faktor-faktor dari dalam diri juga disebabkan faktor lingkungan. Ada beberapa faktor yang mempengaruhi seseorang merokok yaitu, zat nikotin yang membuat seseorang ketagihan, faktor teman, faktor psikologis yang merasa lebih fokus dalam mengerjakan halatau suka memainkan asap [2].

Meskipun jumlah kimia yang ditemukan di rokok elektrik lebih sedikit dibanding rokok tembakau. Liquid vaporizerdan voltase pada baterai memiliki komponen yang berbahaya dan akan semakin berbahaya pada device yang memiliki high-voltage [3].

Vaporizer adalah alat sederhana yang dapat menyalurkan nikotin melalui sistem kerja baterai kedalam tubuh manusia. Nikotin dalam berbagai macam dosis di hisap pengguna melalui tabung. Kebanyakan vaporizer terdiri dari beberapa konten: sebuah baterai litium yang dapat diisi ulang, sebuah atomezer (yang memanaskan cairan sehingga tercipta uap), dan sebuah tabung. Produk standar cairan mengandung nikotin propylene glycol, perasa dan air [4].

Beberapa studi telah dilakukan untuk mengetahui hubungan antara pengguna vaporizer dengan rokok tradisional. Didapat hasil bahwa pengguna vaporizer membantu mereka untk berhenti atau mengurangi kebiasaan merokok mereka [5]. Di Kalimantan Selatan, Banjarmasin pada tahun 2015 Kepala Balai Besar Pengawas Obat dan Makanan menyampaikan bahwa rokok elektrik atau elektronik memiliki kandungan zat yang berbahaya untuk dikonsumsi. Sejak beberapa bulan terkahir, rokok elektrik atau yang kini lebih populer disebut vapor makin marak di kota Banjarmasin. Dari mahasiswa, pelajar, sampai pekerja, tua muda banyak yang menggunakan vapor sebagai pengganti rokok konvensional. Tak Cuma mereka yang ingin beralih dari rokok, vapor juga menjadi lifestyle di kalangan anak muda kebanyakan, baik yang sebelumnya memang sudah merokok [6].

Cafe Lantai Dua Coffe Banjarmasin dipilih dalam penelitian ini, dikarenakan disini adalah tempat orang atau pengunjung sering berkumpul. Dan di sini salah satu cafe yang memperbolehkan pengunjungnya untuk merokok bebas di dalam ruangan cafe tersebut. Dan cafe ini juga tergabung dengan tempat penjualan Vapor. Sehingga peneliti tertarik untuk melakukan penelitian tentang bagaimana tingkat pengetahuan dan sikap pengunjug dengan perilaku merokok di Cafe Lantai Dua Coffe Banjarmasin Tahun 2018.

Berdasarkan survei pendahuluan yang telah dilakukan peneliti pada tanggal 18 April 2018 bahwa Kelurahan Tanjung Pagar dilalui oleh Sungai Kelayan yang memiliki pola aliran sungai yang pasang surut dan merupakan salah satu kategori sungai kecil di Kota Banjarmasin. Pemukiman penduduk di Kelurahan Tanjung Pagar berupa rumah panggung yang badan rumahnya mengambil ruang sungai sehingga badan sungai semakin sempit dan keadaan bangunan terlihat tidak ada ruang terbuka karena letak bangunan yang sangat rapat. Menurut informasi yang didapat peneliti dari Kelurahan Tanjung Pagar bahwa jumlah Wanita Usia Subur (WUS) berkisar umur 15-49 tahun yang sudah menikah tergolong banyak dan sering memanfaatkan sungai untuk mandi, cuci, dan kakus (MCK) walaupun secara fisik dan fisiologis air sungai sudah tidak layak pakai. Air PDAM memang sudah disediakan oleh pemerintah namun sering terjadi ketidaklancaran air tersebut masuk ke Kelurahan Tanjung Pagar sehingga air PDAM hanya dipakai untuk minum ataupun memasak saja. 
Berdasarkan latar belakang tersebut peneliti merasa tertarik untuk melakukan penelitian mengenai "Hubungan Personal Hygiene dan Penggunaan Kontrasepsi Dengan Kejadian Keputihan Pada Wanita Usia Subur (WUS) Di Kelurahan Tanjung Pagar Banjarmasin”.

\section{METODE}

Jenis penelitian yang digunakan dalam penelitian ini adalah survey analitik dengan pendekatan Cross Sectional. Populasi dalam penelitian ini adalah seluruh pengunjung di Cafe Lantai Dua Coffe Banjarmasin Tahun 2018 yaitu 150 orang dari bulan Januari - Maret 2018. Jumlah sampel pada penelitian ini diambil sebanyak 50\% dari populasi yaitu sebanyak 75 orang. Sampling dalam penelitian ini menggunakan teknik Accidental Sampling dimana ini dilakukan dengan pengambilan responden secara kebetulan ada atau tersedia di tempat tersebut sesuai dengan konteks penelitian. Instrumen yang digunakan dalam penelitian ini adalah kuesioner.

\section{HASIL}

Berdasarkan analisa data pada table 1, menunjukkan bahwa proporsi responden perilaku tidak merokok sebanyak 33 responden (44\%), sedangkan responden yang merokok sebanyak 42 responden (56). Pengetahuan responden tentang rokok kategori baik sebanyak 32 orang (42,7\%), pengetahuan responden cukup sebanyak 24 orang (32\%), dan pengetahuan responden kurang sebanyak 19 orang (25,3\%). Dengan demikian dapat dikatakan pengetahuan Pengunjung Cafe Lantai Dua Banjarmasin Tahun 2018 memiliki kategori baik. Sebagian besar responden memiliki sikap yang positif sebanyak 59 orang ( $78,7 \%$ ), sedangkan responden yang memiliki sikap negatif sebanyak 16 orang ( $21,3 \%$ ). Dengan demikian dapat dikatakan sebagian besar pengunjung Cafe Lantai Dua Coffe Banjarmasin memiliki sikap yang positif.

Tabel 1. Distribusi Hubungan Pengetahuan Responden Dengan Perilaku Merokok pada Pengunjung di Cafe Lantai Dua Coffe Banjarmasin Tahun 2018

\begin{tabular}{cccccccc}
\hline & \multicolumn{4}{c}{ Perilaku Merokok } & \multicolumn{2}{c}{ TOTAL } & \multirow{2}{*}{$\begin{array}{c}\boldsymbol{P} \\
\text { Pengetahuan }\end{array}$} \\
\cline { 2 - 6 } & \multicolumn{2}{c}{ Tidak Merokok } & \multicolumn{2}{c}{ Merokok } & \multirow{2}{*}{$\mathbf{N}$} & $\mathbf{\%}$ & \\
\cline { 2 - 6 } & $\mathbf{N}$ & $\mathbf{\%}$ & $\mathbf{n}$ & $\mathbf{\%}$ & & \\
\hline Baik & 20 & 62,5 & 12 & 37,5 & 32 & 100 \\
\hline Cukup & 6 & 25,0 & 18 & 75,0 & 24 & 100 & 0,015 \\
\hline Kurang & 7 & 36,8 & 12 & 63,2 & 19 & 100 \\
\hline Total & $\mathbf{3 3}$ & $\mathbf{4 4 , 0}$ & $\mathbf{4 2}$ & $\mathbf{5 6 , 0}$ & $\mathbf{7 5}$ & $\mathbf{1 0 0}$ \\
\hline
\end{tabular}

Berdasarkan analisis data pada table 2, menunjukkan bahwa pengetahuan dari 32 responden kategori baik dengan perilaku tidak merokok sebanyak 20 responden (62,5\%) dan 12 (37,5\%) dengan pengetahuan baik memiliki perilaku yang merokok. Sedangkan pengetahuan dari 24 responden pengetahuan cukup dengan perilaku tidak merokok sebanyak 6 responden $(25,0 \%)$ dan 18 (75,0 \%) dengan pengetahuan cukup memiliki perilaku merokok. Dan pengetahuan dari 19 responden kategori kurang dengan perilaku tidak merokok sebanyak 7 responden (36,8 \%) dan 12 responden (63,2\%) dengan pengetahuan kurang memiliki perilaku merokok. Dari hasil distribusi hubungan didapatkan bahwa pada tabel $3 \times 2$ tidak ditemukan cell ( 0 cell), maka pengujian statistik yang digunakan yaitu Uji Chi Square didapatkan nilai $\mathrm{p}=0,015(\mathrm{p}<0,05)$ yang menunjukkan bahwa ada hubungan antara variabel pengetahuan dengan variabel perilaku merokok pada penelitian ini. Bedasarkan data tersebut didapatkan hasil dari 59 re- 
sponden yang tidak merokok mempunyai sikap positif sebanyak 33 responden (55,9\%) dan 26 responden (44,1\%) dengan perilakumerokok. Sedangkan dari 16 responden mempunyai sikap negatif (100\%) dengan perilaku merokok. Dari hasil distribusi hubungan didapatkan bahwa pada tabel $2 \times 2$ tidak ditemukan cell (0 cell ) maka pengujian statistik yang digunakan yaitu Uji Chi Square didapatakan nilai $\mathrm{p}=0,000(\mathrm{p}<0,05)$ yang menunjukkan bahwa ada hubungan antara variabel sikap dengan variabel perilaku merokok pada penelitian ini.

Tabel 2. Distribusi Hubungan Sikap Responden Dengan Perilaku Merokok pada Pengunjung Cafe Lantai Dua Coffe Banjarmasin Tahun 2018

\begin{tabular}{lcccccccc}
\hline & & \multicolumn{4}{c}{ Perilaku Merokok } & \multicolumn{2}{c}{ TOTAL } & \multirow{2}{*}{$\boldsymbol{P}$} \\
\cline { 3 - 6 } No. & Sikap & \multicolumn{2}{c}{ Tidak Merokok } & \multicolumn{2}{c}{ Merokok } & \multirow{2}{*}{ N } & Value \\
\cline { 3 - 7 } & & $\mathbf{N}$ & $\mathbf{\%}$ & $\mathbf{n}$ & $\mathbf{\%}$ & & \multirow{2}{*}{0,000} \\
\hline 1. & Positif & 33 & 55,9 & 26 & 44,1 & 59 & 100 \\
\hline 2. & Negatif & 0 & 0,0 & 16 & 100 & 16 & 100 \\
\hline & Total & $\mathbf{3 3}$ & $\mathbf{4 4 , 0}$ & $\mathbf{4 2}$ & $\mathbf{5 6 , 0}$ & $\mathbf{7 5}$ & $\mathbf{1 0 0}$ \\
\hline
\end{tabular}

\section{PEMBAHASAN}

Cafe Lantai Dua Coffe Banjarmasin merupakan salah satu cafe yang belum menerapkan peraturan tentang larangan merokok sesuai dengan Perda Kota Banjarmasin no.7 tahun 2013 tentang Kawasan Tanpa Rokok (KTR). Berdasarkan hasil penelitian terhadap perilaku merokok yang dilakukan di Cafe Lantai Dua Coffe Banjarmasin menunjukkan bahwa dari 76 responden sebanyak 33 pengunjung $(44,0 \%)$ tidak merokok dan sebanyak $42(56,0 \%)$ pengunjung yang merokok.

Berdasarkan penelitian yang telah dilakukan menunjukkan bahwa pengetahuan pengunjung Cafe Lantai Dua Coffe Banjarmasin paling banyak alam kategorik pengetahuan baik dan paling sedikit dalam kategori pengetahuan kurang. Hal ini terlihat dari tabel 4.2 bahwa yang memiliki pengetahuan baik sebanyak 32 pengujung (42,7 \%), cukup 24 (32,0 \%) dan kurang 19 (25,3\%). Berdasarkan ketepatan jawaban responden dari kuesioner pengetahuan yang telah dibagikan diperoleh pertanyaan yang paling banyak dijawab yaitu pertanyaan tentang pengertian rokok tembakau dan rokok elektrik, dimana pengetahuan mereka sebagian besar sudah tahu apa bahaya rokok bagi si perokok ataupun orang-orang disekitarnya. Dari hasil penelitian yang dilakukan menunjukkan bahwa sebagian besar pengunjun berada diusia 18-21 tahun yang mana masuk kategori remaja akhir, pada tahap ini remaja akhir mengalami pertumbuhan dan perkembangan baik dari fisik maupun psikososial.

Berdasarkan penelitian yang telah dilakukan menunjukan bahwa sikap pengunjung cafe lantai dua coffe banjarmasin sebagian besar dalam kategori positif. Hal ini terlihat dari tabel 4.3 bahwa yang mempunyai sikap positif sebanyak 59 pengunjung $(78,7 \%)$ dan sikap negatif 16 pengunjung $(21,3 \%)$ dari 75 pengunjung ada 59 yang mempunyai sikap positif dengan menjawab pernyataan positif dan negatif dengan benar dan sesuai dengan sikap mereka masing-masing. Dari sikap positif sebagian besar menjawab rokok tembakau dan rokok elektrik sama-sama membahayakan bagi kesehatan. Dan yang menjawab negatif sebagian besar menjawab rokok elektrik mempunyai wangi yang enak sehingga tidak mengganggu orang sekitar.

Berdasarkan hasil penelitian yang dilakukan, menunjukkan bahwa ada hubungan antara pengetahuan dengan perilaku merokok pada pengunjung secara statistik dari 75 responden dengan menggunakan analisis Chi Square 
didapatkan nilai $\mathrm{p}=0,015(\mathrm{p}<0,05)$. Hasil penelitian yang didapat dari jawaban responden sebagian besar pengunjung memiliki pengetahuan yang baik mengenai bahan yang terkandung dalam rokok tembakau maupun rokok elektrik, namun ada beberapa pengunjung yang memiliki pengetahuan baik tapi masih tetap melakukan tindakan merokok. Dari pengetahuan yang cukup dan kurang dimana sebagian besar pengunjung memang merokok. Pengetahuan mengenai rokok saat ini bisa dipelajari dan mudah didapatkan dari berbagai hal. Secara keseluruhan terlihat bahwa sebagian besar pengunjung mengetahui definisi dari rokok namun ada juga beberapa pengunjung yang mempunyai pengetahuan cukup akan tetapi mereka adalah pengunjung yang merokok.

Berdasarkan hasil yang diuji secara statistik dari 75 responden dengan menggunakan analisis Chi Square didapatkan nilai $\mathrm{p}=0,000(\mathrm{p}<0,05)$ yang menunjukkan bahwa ada hubungan antara variabel sikap dengan variabel perilaku merokok. Sebagian besar pengunjung memiliki sikap yang positif kalau merokok sangatlah berbahaya bagi kesehatan si perokok maupun orang disekitarnya. Namun terdapat beberapa pengunjung yang memiliki sikap positif tapi mereka adalah pengunjung yang merokok. Diketahui bahwa sikap positif dan negatif mengenaibebas merokok dimana saja dan bahaya rokok elektrik maupun rokok tembakau dapat membahayakan si perokok maupun orang disekitarnya dan sebagian besar mereka menjawab sangat tidak setuju bebas merokok dimana saja.

Perilaku merokok berawal dari mengimitasi keluarga yaitu orang tua dan lingkungan sosial yaitu orangorang yang lebih dewasa maupun teman sebaya. Imitasi merupakan dorongan untuk meniru orang lain. Imitasi tidak berlangsung secara otomatis melainkan dipengaruhi oleh sikap menerima dan mengagumi terhadap apa yang diimitasi, Selain itu alasan anak merokok yaitu keinginan yang besar untuk mencoba, paksaan yang dilakukan teman, ajakan merokok oleh teman, keenggaan menolak ajakan teman merokok, ikut-ikut teman yang merokok dan perasaan iri yang timbul ketika teman sebaya merokok serta agar terlihat bergaya didepan teman-teman yang lain. Merokok juga dapat membuat anak diterima di lingkungan sosialnya, dengan teman-teman yang merokok mereka merasa mempunyai nilai lebih ketika bergaya [7]-[13].

\section{KESIMPULAN DAN SARAN}

Pengetahuan responden tentang perilaku merokok di Cafe Lantai Dua Coffe Banjarmasin Tahun 2018 diketahui sebagian besar pengetahuan responden kategori baik sebanyak $32(42,7 \%)$ dari pengetahuan cukup dan kurang. Sikap responden tentang perilaku merokok di Cafe Lantai Dua Coffe Banjarmasin Tahun 2018 diketahui sebagian besar sikap responden kategori positif sebanyak 59 (78,7\%). Perilaku merokok responden Cafe Lantai Dua Coffe Banjarmasin Tahun 2018 diperoleh hasil sebanyak 42 responden (56\%) yang merokok. Ada hubungan antara pengetahuan dengan perilaku merokok pada pengunjung Cafe Lantai Dua Coffe Banjarmasin Tahun 2018, dengan nilai $\mathrm{p}=0,015$. Ada hubungan antara sikap dengan perilaku merokok pada Pengunjung Cafe Lantai Dua Coffe Banjarmasin Tahun 2018, dengan nilai $\mathrm{p}=0,000$. Penelitian ini merekomendasikan untuk menerapkan secara efektif Perda Kota Banjarmasin Tahun 2013 tentang Kawasan Tanpa Rokok (KTR) dan disarankan kepada pemilik cafe untuk memisahkan antara Vape Store dengan Cafe, karena tidak semua orang terbiasa dengan asap rokok. Bagi pengunjung yang merokok diharapkan pengunjung yang merokok agar menghentikan kebiasaan merokok tersebut. Perilaku merokok adalah suatu perbuatan yang tidak baik bagi generasi muda kelak. Bagi pengunjung tidak merokok diharapkan pengunjung yang tidak merokok untuk tetap menjaga kebiasaan tersebut dan tidak terpengaruh oleh ajakan teman sebaya atau iklan. Sudah seharusnya kita agar tetap menjaga kesehatan dimana kita ketahui merokok merupakan penyakit tidak menular yang dapat memicu berbagai penyakit seperti kanker paru dan lain sebagainya. Bagi peneliti selanjutnya diharapkan bisa menggunakan cakupan responden yang lebih luas, memperbanyak variabel dependen 
dan variabel independen lain yang berhubungan dengan perilaku merokok dan desain penelitian yang berbeda untuk dapat mengembangkan penelitian.

\section{DAFTAR PUSTAKA}

[1] World Health Organization, "WHO | Tobacco," Who. 2015.

[2] B. A. Putra, "Hubungan Antara Intensitas Perilaku Merokok dengan Tingkat Insomnia (Studi pada Mahasiswa yang Merokok Sekaligus Mengalami Insomnia di Angkringan sekitar Universitas Negeri Semarang," Skripsi, 2013.

[3] M. F. Indra, Y. Hasneli N, and S. Utami, "Gambaran Psikologis Perokok Tembakau Yang Beralih Menggunakan Rokok Elektrik (Vaporizer)," Jom, 2015.

[4] C. Lanz, J. Mattsson, U. Soydaner, and R. Brenneisen, "Medicinal Cannabis: In Vitro Validation of Vaporizers for the Smoke-Free Inhalation of Cannabis," PLoS One, 2016.

[5] J. Fischedick, F. Van Der Kooy, and R. Verpoorte, "Cannabinoid Receptor 1 Binding Activity and Quantitative Analysis of Cannabis sativa L. Smoke and Vapor," Chem. Pharm. Bull. (Tokyo)., 2010.

[6] C. Hindocha, T. P. Freeman, J. A. Ferris, M. T. Lynskey, and A. R. Winstock, "No smoke without tobacco: A global overview of cannabis and tobacco routes of administration and their association with intention to quit," Front. Psychiatry, 2016.

[7] D. K. Wulan, "Faktor Psikologis yang Mempengaruhi Perilaku Merokok pada Remaja," Humaniora, 2017.

[8] A. Alamsyah, "DETERMINAN PERILAKU MEROKOK PADA REMAJA,” J. Endur., 2017.

[9] dan M. E. Ari Tris Ochtia Sari, Neila Ramdhan, "Empati Dan Perilaku Merokok Di Tempat Umum," Empati Dan Perilaku Merokok Di Tempat Umum, 2003.

[10] S. Trixie and R. Amalia, "Perilaku Merokok Di Kalangan Mahasiswa Universitas Muhammadiyah Semarang," Pros. Semin. Nas., 2010.

[11] Y. S. Prabandari, Nawi, and P. R. Siwi, "Rokok Terhadap Perilaku Dan Status Merokok Mahasiswa," J. Manaj. Pelayanan Kesehat., 2009.

[12] R. Rosita, D. L. Suswardanya, and Z. Abidin, "Penentu Keberhasilan Berhenti Merokok Pada Mahasiswa," J. Kesehat. Masy., 2012.

[13] I. K. Nasution, "Perilaku Merokok pada Remaja," Univ. Sumatera Utara, 2008. 